\section{Novos olhares sobre a imigração boliviana}

\author{
Oswaldo M. S. Truzzi ${ }^{\star}$
}

BAENINGER, Rosana (Org.).
Imigração boliviana no Brasil.
Campinas: Nepo/Unicamp, 2012.

A presença cada vez mais constante de bolivianos no Brasil é sinal inequívoco tanto dos tempos de globalização, quanto da inserção irremediável de nosso país no panorama de acolhimento de fluxos migratórios na América Latina. O livro organizado por Rosana Baeninger - fruto do Projeto Observatório das Migrações em São Paulo: fases e faces do fenômeno migratório no Estado de São Paulo, financiado pela Fapesp - perfila, com grande acuidade e percepção, os aspectos mais notáveis da presença desses imigrantes na capital paulista, seu destino preferencial, bem como em áreas fronteiriças entre os dois países.

Já no primeiro capítulo, a própria organizadora situa os marcos contextuais principais do fenômeno no processo de reestruturação econômica internacional, que redefine uma espécie de hierarquia de destinos migratórios ao nível mundial. Embasada em dados referentes a 1990 e 2000 publicados pelo Celade (Centro Latinoamericano y Caribeño de Demografia), Baeninger descreve as principais tendências dos movimentos internacionais de população entre países da América Latina e Caribe, apontando, em particular, as distintas modalidades de migrações que o Brasil tanto acolhe quanto envia, além de diagnosticar uma heterogeneidade de situações, entre as quais aflora o fluxo crescente de bolivianos ao Brasil.
No artigo seguinte, Sidney Silva, um dos pioneiros nos estudos sobre imigrantes bolivianos em São Paulo, toma suas manifestações culturais como pretexto para discutir as diferenças culturais e preconceitos atribuídos e vivenciados pelo grupo em seu relacionamento com a sociedade inclusiva. Tema semelhante merece a atenção de Dominique Vidal, ao discutir as relações de alteridade entre brasileiros e bolivianos, tendo como campo empírico os bairros centrais de São Paulo. Após constatar a vigência de relações pouco hostis, mas também relativamente fluidas entre os dois grupos, o autor descreve que a percepção nativa da presença dos bolivianos é estruturada pelas categorias da "indianidade", da cultura singular e do trabalho escravo.

Um desdobramento de tal temática pode ser encontrado no artigo assinado por Szilvia Simai e Rosana Baeninger, que apresenta como novidade a análise dos construtos discursivos de brasileiros e bolivianos, em convivência na metrópole paulistana. Em uma pesquisa conduzida a partir de grupos focais e entrevistas em profundidade, as autoras indicam "o proeminente papel que a negação (do preconceito, dos conflitos etc.) desempenha no discurso contemporâneo em relação às questões raciais e étnicas entre os imigrantes bolivianos e brasileiros na cidade de São Paulo". A análise do discurso serve igualmente como metodologia para Alex Manetta destacar como a mídia jornalística vem contribuindo para a geração e manutenção de estereótipos relacionados ao crime, à miséria e à contravenção, entre imigrantes bolivianos no Brasil.

Dois artigos, um assinado por Sylvain Souchaud e outro por Patrícia Tavares de Freitas, têm em comum a perspectiva de ampliar e re-enquadrar nossa compreensão acerca da inserção de bolivianos no setor específico das confecções. O primeiro deles questiona a noção de que a indústria de confecções tenha se constituído em São Paulo como um nicho étnico, específico de

\footnotetext{
* Doutor em Ciências Sociais pela Unicamp, professor associado da Universidade Federal de São Carlos - UFSCar (truzzi@ufscar.br).
} 
bolivianos. De fato, o autor elabora uma série de considerações no sentido de fortalecer o argumento de que se trata de um nicho econômico, disposto a acolher imigrantes de várias origens, a exemplo do que ocorreu com coreanos e paraguaios. Por sua vez, Patrícia anuncia as vantagens de se trabaIhar com o conceito de "territórios circulatórios", desenvolvido por Alain Tarrius, no caso específico da indústria de confecções. Argumenta a autora ser esta abordagem mais adequada para captar como tais territórios, por onde transitam grupos migratórios distintos, encontram-se totalmente subordinados a determinados fluxos, tempos, ritmos e sequências que articulam trajetórias individuais e intergeracionais, bem como trajetos (ritmos) cotidianos. Sua pesquisa, ainda em andamento, promete lançar novas luzes sobre a inserção de imigrantes no setor de confecções em São Paulo.

A implantação territorial dos imigrantes na Região Metropolitana de São Paulo também é objeto de análise do capítulo assinado por lara Rolnik Xavier. Ao interpretar o fenômeno a partir da confluência entre, de um lado, processos urbanos e sociais histórico-estruturais (mercado imobiliário e moradia, acesso a serviços urbanos e ofertas de trabalho) e, de outro, trajetórias dos imigrantes, a autora destaca a diversidade da localização espacial de bolivianos na metrópole, diversidade que obedece a temporalidades distintas inscritas em diferentes projetos migratórios. Em outro capítulo do livro, um sítio mais delimitado - a Praça Kantuta, no bairro do Canindé - é tomado como expressão das configurações existentes entre bolivianos em São Paulo. Ubiratan Silva Alves vale-se do exame de uma atividade de lazer, o futebol, para adentrar nas relações sociais e redes de interdependência entre atores e jogadores, empregadores, associação e frequentadores da praça, alem de discutir características do preconceito associado ao grupo.

As trajetórias, experiências e percepções de quatro estudantes bolivianos na Unicamp constituem o foco da análise de Débora Mazza. Por meio de seus depoimentos, a autora conclui que, entre o sonho aca- lentado da educação superior e a realidade concreta vivenciada, interpõem-se inúmeros desafios a serem superados, tais como a língua, a cultura e os preconceitos. Segundo a autora, o enfrentamento de tais dificuldades, ao invés de nuançar, acaba por fortalecer a identidade de origem. Também jovens de origem boliviana são analisados no capítulo de autoria de Gabriela Camargo de Oliveira e Rosana Baeninger. Tomando como fonte os microdados do Censo 2000 para a cidade de São Paulo, as autoras buscaram detectar a presença de crianças que imigraram jovens (a chamada geração 1,5), ou que já nasceram (com pelo menos um dos pais bolivianos) no Brasil (segunda geração), buscando assim traçar um perfil da estrutura familiar presente em tais domicílios. Elas concluem pela importância de se levar em conta estes jovens estratos da população de bolivianos para a compreensão, com maior riqueza, da dinâmica demográfica e de reprodução do grupo em questão.

Três capítulos focalizam especificamente os bolivianos em regiões de fronteira, dois dos quais são de autoria de Roberta Guimarães Peres. Um deles busca compreender, à luz de uma série histórica de dados censitários, os principais traços da presença boliviana na construção de Corumbá. A autora destaca que Corumbá, além de se constituir em um espaço de fronteira propriamente dito, centralizou uma dinâmica econômica regional que em boa parte justifica a presença boliviana no município. O outro capítulo, assinado também por Roberta, apresenta um corte mais teórico-metodológico, ao discutir as limitações decorrentes da utilização exclusiva dos censos para os estudos migratórios. Ela exemplifica como uma pesquisa de campo complementar em Corumbá pôde iluminar aspectos difíceis de serem captados pela análise censitária, em particular as especificidades da migração feminina.

Por fim, o capítulo assinado por Angela Maria Marques investiga a dinâmica das relações estabelecidas entre Corumbá, no Brasil, e Puerto Quijarro e Puerto Suarez, na Bolívia. Tomando-se como exemplo os serviços de saúde nesta região de fronteira, a autora argumenta que os conceitos de 
circulação, residência-base e reversibilidade renovada podem contribuir para o reconhecimento da região como espaço migratório com características singulares.

Qualquer coletânea de artigos abriga em seu interior altos e baixos, expressões ora de estágios diferenciados na condução das pesquisas, ora do próprio amadurecimento intelectual heterogêneo entre os autores.
De qualquer modo, a obra em seu conjunto é muito interessante por acolher pontos de vista distintos, mas que se complementam por iluminarem ângulos diversificados da experiência dos imigrantes bolivianos em São Paulo e em regiões de fronteira. Por esta razão, o compêndio torna-se leitura obrigatória a todos os interessados em se aprofundar no tema.

Recebido para publicação em 27/05/2012 Aceito para publicação em 03/07/2012 
